\title{
IMPACT OF ADVANCEMENTS IN TECHNOLOGICAL AIDS IN COMMUNICATION MEDIA IN BRINGING ABOUT SOCIAL REFORMATION
}

\author{
Keshav Patel* \\ MGCGVV Chitrakoot (MP), India
}

\begin{abstract}
Communication medium have evolved ever since the ancient times. Indian Hindu mythology provides examples of great communicators like Narad and Hanuman who provide the earliest glimpses of journalism. Interestingly, Hindu mythology and the modern communication media have not been connected, though the literature available brings about valid connections of transformation in this communication media for the purpose of social welfare. The present paper delves into presenting a developmental picture connecting ancient India to the modern India with respect to the communication media and its role in social reformation. Analysis of mythological identities and furthermore through a series of extensive reading done by the author made believe that the motive of journalism and social participation was to bring about a social change. This study is based on connections based on descriptions available on characters and identities from Hindu mythology. The path of development of communication media has been traced down with the technological advancements in the form of chronological development of the aids and their impact on social reformation. The mythological Indian characters have passed on through stories and Vedas which have scattered appearance in the form of concrete literature. It can be seen that communication media has been instrumental in impacting the social reformation at all times.
\end{abstract}

Keywords: Communication medium, social reformation, spiritual India, Modern India

\section{Introduction}

Earliest form of communication in India goes back to the times of Narad. It is stated that Narad was the first amongst those who would move around as a message carrier. James G. Lochtefeld mentions him in following words;

"A famous sage in Hindu mythology, Equally renowned for his qualities as a musician and as a gossip. Narada plays a stringed instrument known as Vina, serving as the bard to the Gods. His ambition as a musician apparently exceeds his actual skill, since several of his mythic stories describe him being humbled. In his capacity as a wandering musician, he also conveys news and gossip. In many cases Narada's news-bearing is the vehicle advancing the plot in a story." (Lochtefeld, 2002)

Maharishi Narad holds an eminent position in all important 'Puranas'. He has been titled as 'Devarshi' but his work was not limited to the 'Devtas'. In some forms he may have been criticized as a conspirator ('Bhedi') but in a true sense he worked towards social reformation using communication as a medium. Devarishi Narad exchanged communication in the interest of the society by large. Many a times his communication appears to have created tension among the Devtas but from the peoples' perspective one can easily see the underlying purpose. It was only through Narad's inspiration that Valmiki wrote Ramayana(T.N.Sethumadhavan, 2010)and Vyas composed Bhagwad Gita(Narasimhan, 2016 ) in the form of epic poems. All his suggestions and statements have an insight towards social welfare. It was he who suggested 'Daitya Andhak' to use the boon received from Lord Shiva on himself. He compelled Ravan to get entangled in Bali's tail and suggested Kans to kill Devaki's children. He went to Indra as Krishna's messenger and asked him to renunciate the ego he has for having kept Krishna devoid of Parijaat(Richa Sharma, 2013). These and many more suggestions of the kind 
bring forth the controversial nature of Narad's personality. But it is worth realizing that in doing all this Narad did not have any self interest. He always had a feeling of collective social welfare. He also benefitted the Demonic powers (Asurs) with his wisdom. When Hiranya left for Mandak mountain for penance, the Devtas started killing the wives of the Danavas. But with the foresightedness that Narad had he could protect Hiranya's wife and Prahlad could be born. And then, by influencing Prahlad with his spiritual wisdom he made Prahlad the means to end Hiranyakashyapa. Despite all these qualities of Narad those that remained unaddressed were his ability and potential of communication. Narad used his voice in such a manner that helped in the development of events. All events influenced by Narad found results in social welfare. In this context, it will not be an exaggeration if Narad is referred as a social communicator. On analyzing the statements, dialogues and events it is proven that, firstly, he was a very skilled and dexterous communicator. Secondly, that his communication was for the social interest. He never had a vested interest and his communication never targeted any section or caste. His communication was always centered towards social welfare. Thirdly, 'Bhakti Sutra' written by Narad which has 84 Sutras tells us that the 'Bhakti marg' a philosophy; as a way for a devotee to attain unison with God. On minutely analyzing these Sutras it is realized that not only for journalism but these are eternal principles for entire media. In the $15^{\text {th }}$ Sutra of the same it has been stated "तल्लक्षणानिवच्यन्तेनानामतभेदात" (there is difference and plurality of opinion) which is the basic principle of journalism

On the other hand, 'Snakes and Ladders' which is a popular traditional game in India has an important role in social reformation. The game was designed by Sant Gyan Dev in the $13^{\text {th }}$ Century A.D. and was then called the 'Moksha Pat'.(Mokshapat: Snake and Ladder had its origin in India, 2018)In this game the ladders represent the boons and snakes the negative traits (curses). The game was played with Cowrie or dices. A lot of changes occurred in the game but its basic meaning remained the same. Good work takes people to heaven whereas the wrong doings brings one back again to the worldly sufferings through the birth cycle.

In the similar way Hanumanji is an example of mass communicator from Treta to Dwapar Yug. In real sense 'Buddhimatamvarishtam'.Hanuman was an artist of mass communication. Sanjay who narrated the first eye account of the 18 days Mahabharata's tale in Kurukshetra, is considered as a leader of communication medium.

\section{Development of technology impacting communication media:}

In India development of media is considered in three phases. First phase is considered from $19^{\text {th }}$ century when India was under the British Regime. In the first phase the foundation was laid at the time dilemma of dissatisfaction was casting its shadows to form the outlines of the social structure under colonial modernization and against colonial governance. During this time, along with the English newspapers, newspapers in other Indian languages also started getting published and radio broadcast started under the British control.

The second phase started with the independence and went on till 80s. In this long duration transmission and quality of media improved exponentially. Their different forms could be seen targeting towards launchingmaking India a modern nation and participating in this big national project. Television came during this period. Print media was majorly privatized while Radio and television was controlled by the government.

Third phase started with the advent of globalization in the 90s. The world squeezed into a small village with the advent of internet and search engines like Google and Yahoo, bringing voluminous information at a mouse click, within ones reach. Information started flowing in to people from all sources. Anyone could find any information from anywhere, and society was witnessing a new revolution in communication media. Every hand had access to information power, to connect and spread it to anyone. This eventually started paving way for evolving a new society. With the up gradation in technology people were further empowered. Computer technology and robotics made a newer intervention that was almost able to substitute human mind. This influenced every aspect of life. We have options of remote operated vehicles to unmanned vehicles. 


\section{Communication medium and social reformation in modern India:}

Recalling the early days of communication, through the theater and projections over Television serials, "suno sunogaonwalon", when these words poured into the ears of the common man with the drums alongside, it was considered to be 'Munadi'(town crier or drummer). Not only Munadi, but Nautanki, duggi peetna, Natya Leela, puppet show, etc. also contributed majorly towards social reformation. Munadi played a vital role in bringing about awareness along with connecting the King and Stately orders through a common platform.

Connecting now with the first phase we can see that the communication media was instrumental not only in raising voice against British Governance and social ill-practices but also in reformation of the society. In the first phase communication medium efforts were made to create awareness and to bring people together against British Government. In this phase communication media was primarily dedicated to the mission of independence movement and freedom from colonial powers.

Post independence these instruments were used to propagate the welfare schemes to the masses and later this is replaced by the advanced technological aids by the use of mechanical aids for voice propagation. Kathputli and Natya Griha is replaced by advanced methods of projections and screens and these screens were instrumental in uniting people of different backgrounds to a single place. In continuation we see the places of such projections as places where mass messages of welfare could be delivered for a desired societal change.

\section{Social media and Social reformation}

Internet today is having its reach to a common man and social media has exercised a very astounding role in communication media. From creating awareness about education to politics, from domestic violence to assertion for one's rights, change can be observed at all ends. Social media became voice for women related issues in particular. Social media platforms like Facebook, Twitter and YouTube are no longer just medium of entertainment. Women all over the world are getting opportunities to voice themselves. Women who are active on social media sites have strongly valued opinions. I remember how women in Turkey promoted a campaign "Don't occupy my space" (Patel, 2014)through micro-blogging site, Twitter. This proved to be an exceptional movement in itself. The movement was against men addressing the compromise women have to make while travelling in the public transport where men tend to deliberately occupy an extended space in a rather relaxed manner forcing women to squeeze in smaller spaces. Thousands of women participating in the campaign also believed that the physical gesture of men sitting with legs spread out also has a lot to do with sexual abuse of women. These Turkish women posted the photographs of such men who would sit with their legs spread out on social media and through "don't occupy my space"(Patel, 2014)and “close your legs" campaign (In Turkey, 2014) and drew the attention of the world towards this issue. As a result, some women in America also posted some similar pictures, under 'One body, one seat' Campaign as reported by an American Newspaper(One body, one seat: Seattle's campaign against the 'manspreading' scourge, 2017) For a country like Turkey this was a very surprising thing. In a country with a small population of 8 Crore, about 1 Crore people use Twitter and out of which 53 percent are women.(---Patel, 2017)In India the presence of social media was felt strongly at the time of Damini episode where rape of a paramedical student resulting in her death brought in the entire nation together. Social media played a vital role in this entire episode. A lot of pages were created with titles like 'Justice for Damini'(JusticeForRapeVictimsInIndia, 2013)'Justice to Nirbhaya', 'RIP Damini'which received 'Likes' and 'Shares 'inhuge numbers. Within 10 days of the accident by $18^{\text {th }}$ December 2012, page titled 'Delhi for Women's safety' was created and “Gang raped in Delhi” was created on $20^{\text {th }}$ December 2012, which received 5000 and 4500 'Likes' in 24 hours respectively. This was a contribution of social media which forced people to come out of their homes. Along with Social awareness, Social media played its role in making the Delhi gang rape case as a matter worth attention and to get the administration on back-foot and forced it to think on lines of making new laws. Another page dedicated to this accident, "Got stared at' also became very popular. People supported this movement not just on Facebook but also through other social media sites. Twitter alone 
received Tweets at a rate of 5781 Tweets a day till $22^{\text {nd }}$ December. On $23^{\text {rd }}$ December it received 15421 Tweets which was maximum on Damini case. The hashtags on Tweeter clearly denote how social media is working for rights of women ad their security. The story of Shehla Masood Murder in Bhopal was also attended broadly on the social media. Shehla Masood was an RTI activist and a Social worker who was murdered by a known acquaintance Zahida Parvez. People in Madhya Pradesh came down on streets by the medium of Facebook, Twitter and WhatsApp, to address this very high-profile murder case. Candle light marches were conducted and the administration was forced to take immediate action. Due to interventions of social media Arushi murder case was not only reopened but was reasonable proceedings were also done.

\section{Evaluation of Social reformation}

There is no empirical tool to evaluate reformation. It is a matter of observation in the changes brought about in the social context. Therefore, reformation can be evaluated in terms of impact created by large on the society. Not all reformations result to enactment of laws, but those that make a significant impact bring about a change in the thinking and behavior of the people of the community by large. During the course of study, I observed some of the areas have received a significant change in the form of law enforcements as a result of newer communication streams that opened as a result of new media. Stringent measures towards women security and protection, Protection of Child Rights, Senior Citizens, refinement in the POSCO act, debate on RTI Act are some examples that have been directly impacted by social media.

$3^{\text {rd }}$ of February,2013 gave criminal law ordinance which was presented suggesting changes in Section 181 and 182 , strengthening the laws against rapists was not only the result of reporting of the major news dailies but also participation of people over social media. 22 $2^{\text {nd }}$ December 2015 passed Juvenile justice Bill in legislature, making stringent impositions on those above the age of 16 having involved in an act of sexual molestation. In 2013 the Government released an amount of INR $1000 \mathrm{Cr}$ towards strengthening women protection system.(Development, 2015)This was possible only with the massive intervention of the social media. Another instance where social media silently but strongly impacted a social change was towards the issue of the senior citizens. Massive projection of lack of care of senior citizens was brought about on social media silently. This has finally, lead to an enactment punishing the children who do not maintain the upkeep of their elderly parents under Maintenance of Senior Citizens Act 2007.

21 types of disabilities have come under the aegis of Rights of persons with disability Act, 2017(Justice, 2016), as a result of sensitization towards various disabilities brought about through media.

A numerous Public Interest Litigations have been filed in the courts as a result of the interactions propagated over social media. The debate over the SC/ ST protection Act, brought about rethinking on the side of the government, only due to the voices raised over media.

The minor issues affecting common man and his life started amassing over different veins of media pressurizing the contemporary government to pay heed to them.

\section{Conclusion}

There are no two opinions on the fact that communication media has always been instrumental in social reformation. Narad remained instrumental in removing the social evils as a skilled communicator and Hanuman presented the state of facts before Sita. In Gita, Krishna brought about the reality of the worldly affairs to Arjun and encouraged him to fight 'Adharma' and thereby became instrumental in liberating the world from lawlessness. In the present times of New Media, social media came up as a strong medium to voice against corruption and to voice for ones rights. From Anna Hazare's movement to Nirbhaya Murder case it was key to bringing the whole world together and bring about a revolution of a new kind. It is hence undisputed that from the Ancient times till the modern times communication media has worked strongly for Social reformation. 


\section{References}

(2018, 09 2018). Retrieved from hindi.speakingtree.in: https://hindi.speakingtree.in/allslides/content-36975

Development, M. o. (2015, 03 25). FRAMEWORK FOR NIRBHAYA FUND. Retrieved from http://www.wcd.nic.in: http://www.wcd.nic.in

In Turkey, W. S. (2014, 04 25). In Turkey, Women Shame Male Passengers With 'Close Your Legs' Twitter Campaign. Retrieved from huffingtonpost.in: https://www.huffingtonpost.in/entry/turkey-close-yourlegs_n_5208432

Justice to Nirbhaya. (n.d.). Retrieved from facebook : https://www.facebook.com/pg/Justice-to-Nirbhaya344270289117370/about/?ref=page_internal

JUSTICE, M. O. (2016, 28 16). THE RIGHTS OF PERSONS WITH DISABILITIES ACT, 2016. Retrieved from www.disabilityaffairs.gov.in:

http://www.disabilityaffairs.gov.in/upload/uploadfiles/files/RPWD\%20ACT\%202016.pdf

JusticeForRapeVictimsInIndia. (2013, 03). Retrieved from facebook : https://www.facebook.com/JusticeForRapeVictimsInIndia/

Lochtefeld, J. (2002). The Illustrated Encyclopedia Of Hinduism. New York: The Rosen Publishing Group,Inc.

Mokshapat: Snake and Ladder had its origin in India. (2018, 09 24). Retrieved from Veda: http://veda.wikidot.com/tip:mokshapat

narasimhan, c. s. (2016, 12 24). The story of how Vyasa got inspired to compose Bhagavata. Retrieved from csnarasimhan.wordpress.com: https://csnarasimhan.wordpress.com

nirbhaya. (2015, 03 25). Retrieved from http://www.wcd.nic.in/schemes: http://www.wcd.nic.in/schemes

One body, one seat: Seattle's campaign against the 'manspreading' scourge. (2017, 01 17). Retrieved from reuters: https://www.reuters.com

patel, K. (2014). क्या सोशल मीडिया लैंगिग समानता का उपकरण है ? In Rama, सोशल मीडिया और स्त्री. New Delhi : Northern Book Centre.

Patel, K. (2017). Lok Sabha 2014, Narendra Modi And Social Sites. International Journal of Recent Advances in Psychology $\backslash \&$ Psychotherapy, 1(1).

RICHA SHARMA. (2013, 10 04). The Legacy of Narad Muni. Retrieved from speakingtree.in: https://www.speakingtree.in/allslides/the-legacy-of-narad-muni

T.N.Sethumadhavan. (2010, 09 01). Adhyatma Ramayana, The Spiritual Version of the Story of Sri Rama. Retrieved from www.esamskriti.com: https://www.esamskriti.com/e/Spirituality/Philosophy/AdhyatmaRamayana,-The-Spiritual-Version-of-the-Story-of-Sri-Rama-1.aspx 